\title{
Implementation of Guided Discovery Learning to Improve Student Science Process Skills of Junior High School
}

\author{
Astutik Sri Handayani \\ SMP Negeri 1 Blega \\ Bangkalan, Indonesia
}

\author{
Tjandra Kirana,Yuni Sri Rahayu, Puji Jayanti \\ Department of Science Education, Postgraduated Program \\ Universitas Negeri Surabaya \\ Surabaya, Indonesia \\ yunirahayu@unesa.ac.id
}

\begin{abstract}
One of the central problems of education in Indonesia was the achievement of student learning outcomes that were still needed to be enhanced. It was accordance with the results of preliminary research on the science learning outcome of student in SMPN (State Junior High School) 1 Blega, Indonesia. It was likely due to low process skills. In this study, guided discovery learning model was implemented to investigated the effectiveness of guided discovery learning on students science process skills and students learning outcomes. This study was implemented One Group Pretest-Postest design. The data was analyzed descriptively and the result showed that the persentage of student's mastery learning of science process skill was $100 \%$ and student's cognitive learning result was $93 \%$, with increasing in both scores of $\mathbf{7 1 \%}$. The most dominant student activity was science process skill activities $(20,07 \%)$, supported also by positive student's responses to learning process. This study was proved that guided discovery learning was effective to enhance students science process skills and student learning outcomes.
\end{abstract}

Keywords - guided discovery, science process skills, learning outcome

\section{INTRODUCTION}

In the $21^{\text {st }}$ century, Science and Technology was develop rapidly to help citizens life more easily [1]. The direction of learning process is focused on the skills that was needed in the $21^{\text {st }}$ century include communication skills, critical thinking, creative thinking, problem-solving skills and using ICT skills [2]; [3]. This is in line with the elementary and secondary education goals in Indonesia that is to build a strong foundation for the development of the potential of learners to become human beings who believe and piety to Allah, excellent in character and personality, knowledgeable, competent, critical, creative, innovative, independent and confident, tolerant, democratic and responsible [4]

Teachers have an important role in order to achieve educational goals. Teachers' tasks not only convey information to learners, but should be facilitators who provide the best learning environtment for all learners so they can learn in a fun, joyful, passionate, and brave to make suggestion openly as a basic capital for learners to grow and develop into human beings that ready to adapt, face possibilities, and enter a challenging era of globalization [5]

One of the skills that needed to learn science especially to overcome the challenges of the twenty first century in science and technology sector is science process skills [6]. Science process skills not only a learning approach but also as a result of learning. It is a basic skills in science and a tools of scientist to investigate the science phenomena [7]Science process skills is an important aspect to be mastery by students in order to achieve good knowledge in scientific investigations as part of cognitive and investigative skills [8][9] [10]Science process skills can be categorized into two; ie basic and integrated skills. Basic science process skills consist of observing, measuring, classifying, using space and time relationships, using numbers, summing up, predicting, and communicating. While integrated science process skills include recognizing variables, make data tables, graphs, describing relationships between variables, collect and process data, analyze research, collect hypotheses, define variables, design research, and experiment [11]

One of the main problems in learning process was the low of students science learning outcomes in junior high school. The low learning outcomes of students may be due to the low level of students' science process skills. Students who are given science process skills based learning are more successful than students who are given conventional learning [12]there is an improvement in student achievement at the end of science process skills training in practical activities in the laboratory. In addition to improving academic achievement, science process skills can be used to enhance students' scientific creativity. Science process skills are used by scientists to construct science, find problems, and make conclusions [13] [14]Science process skills can be developed in a scientific investigativebased learning [15][16]

The preliminary study in SMPN 1 Blega showed that the achievement of the students' science process skills in junior high school had not shown the expected results with the following indicator values: 1) $41 \%$ identification of variable, 
$33 \%$ hypothesis formulation, $20 \%$ variable operational definition, $30 \%$ data interpretation, designing experiment $25 \%$ with mastery learning of $6,35 \%$. The results of students' science process skills in the initial study were still low in line with the results of class supervision conducted on teachers of National Examination subjects in SMP Negeri 1 Blega, which showed that $85 \%$ of teachers still using teacher-center learning methods. In this method the teacher performs a "transfer of knowledge" or just transferring knowledge without developing how to learn and how the learning process was implemented.

Teachers' methods in conveying learning materials will determine the achievement of learning goals. There are many choices of teaching models that teachers can use. Teachers are supposed to choose learning methods wisely in accordance with the characteristics of teaching materials and students who are the subject of learning. Guided discovery learning is one of an alternative that can be used to enhance students' science process skills in junior high school.

Learning process with guided discovery learning can provide active learning conditions to students. This learning emphasizes on the problem-solving process faced scientifically. Students not only take notes and memorize the material, but students think actively and ultimately can make conclusions with teacher guidance [17] Using a learning approach with guided learning discovery, student is more active than traditional methods such as more effective for problem-solving, decision-making, critical thinking, creative thinking and interpersonal skills [18]Students learn better when they lead through activities that allow them to find concepts for themselves by being guided by the teacher [19]

In contrast to discovery learning, in guided discovery learning, students are still receiving assistance in the form of teacher guidance so that students will be more focused in achieving learning goals. The things that need to be done in planning and preparing learning guided discovery to take place smoothly are as follows; (1) determine the desired goals that students will learn, (2) choose methods that appropriate to discovery activities, (3) determine the data observation sheets that students will use, (4) prepare tools and materials completely, (5) determine carefully whether students will work individually or in groups, (6) try in advance of the activities that will be done by the students, to know the difficulties that may occur or the possibility to be modified so that the learning can achieve the desired goal [20]

The implementation of guided discovery methods in learning has advantages and disadvantages. Some of the advantages of learning with guided discovery are to increase students' understanding of a concept [21], to train critical thinking skills [22] to make it easier for students to remember a concept longer than traditional learning [23] and to provide students with an opportunity to build their own understanding. While the weaknesses of the implementation of guided discovery learning are: (1) for certain materials, time taken longer, (2) not all students can follow the lesson in this way, in the field some students are still accustomed and easy to understand by lecture model (3) not all topics are suitable to delivered with this model. Generally, the principles related topics can be developed by guided discovery methods [24]
Guided discovery learning activities have similarities with the process-oriented learning activities. Both are learning that emphasizes direct learning experience so that students have to be actively involved in the learning process, so guided discovery and scince process skills has a similar advantages due to the same investigation activities and also finding the concept.

\section{METHODS}

This research was a classroom action research by implementation of guided discovery methods. The study was arranged in Pre-test and Post-Test Group Design with 50 students of $8^{\text {th }}$ grade in SMPN 1 Blega, by using descriptive research. Descriptive research is a kind of method for describing and interpreting objects as real. Some steps are obtained as follows:

\section{A. Planning Stage}

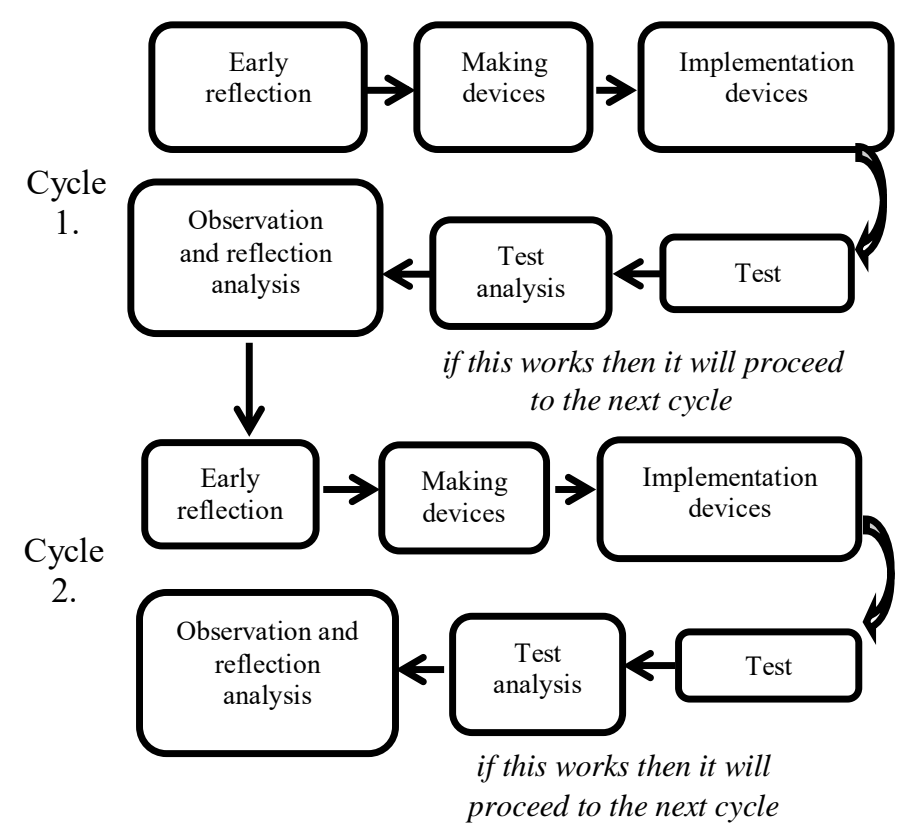

Fig. 1. Class Action Research Procedures

\section{B. Implementation Stage}

In the implementation stage of learning in all three cycles carried out with guided discovery learning with the following material details; (1) Action one, the teacher conveys the concept of the human respiratory system sub concept of the Respiratory Organs; (2) Action two, the teacher conveys the concept of human respiratory system subconseps of the human respiratory process and (3) Action three, the teacher conveys the concept of the human respiratory system subconseps of breathing system measuring the lung volume.

\section{Observation Stage}


The observation stage was carried out in the hope that it will give an idea of the changes that occur to the students.

\section{Reflection Stage}

This stage was done at the end of each cycle. Reflection is done on the research data obtained during the research process to analyze the actions performed and the effect on the learning process. Analysis research then used as a reference to take action on the next cycle.

The variables observed in this research were; (1) The implementation of the learning process; (2) student activities during the learning process; (3) Student response after following the learning process; (4) Outcomes of student process skills; (5) Improvement of learning outcomes.

The required research data was collected using the research instrument such as (1) the observation sheet of the implementation of the lesson plan; (2) Observation sheets of student activities during the learning process; (3) Questionnaire student response after following the learning process and (4) Process skill test, while data collection technique used; (1) Observation for the implementation of learning process, and student activity; (2) Dissemination of questionnaire to find out student responses; (3) Testing: a quiz-shaped test to find out the results of the action on the students' learning outcomes and the final test to determine the improvement of student learning outcomes.

The data obtained then analyzed descriptively qualitative. Observation of the implementation of the lesson plan was implemented following the implementation of the plan in each phase of the guided discovery method then converted using criteria; 1) good with a score of $3.50-4.00$; 2) enough with a score of $3.00-3.49 ; 3$ ) less good with score $2.00-2,90$; 4) not good with a score of 0.00-1.99. The student activity data was obtained from the observers by calculating the frequency of each student activity in persentage (\%). Student's learning mastery was based on minimum standard value of Education Unit where the research was conducted. Improved learning outcomes were identified using the $\mathrm{N}$-gains score, with the high category if $(\mathrm{g})>0.7$, medium category with $0.7 \geq(\mathrm{g}) \geq$ 0.3 , and low category if $(\mathrm{g})<0.3$.

\section{Results AND DisCUSSION}

The lesson plan implementation was observed by two observers on each guided discovery syntax. The results were shown in the following diagram:

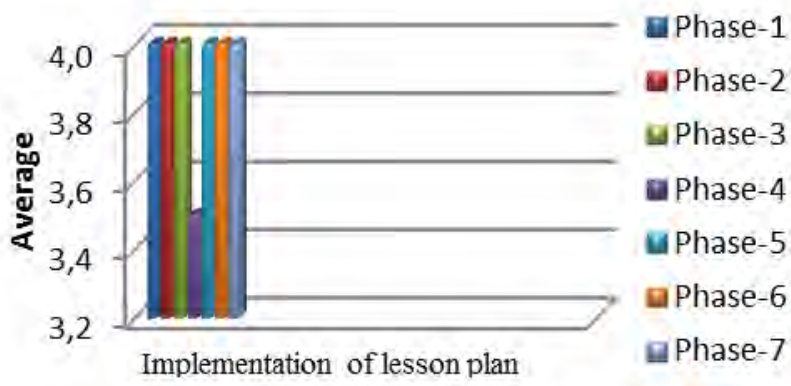

Fig. 2. Observation results of lesson plan implementation with guided discovery method to facilitate the science process skills

The ability of teachers in managing learning processes with guided discovery methods in an effort to enhance students' science process skills could be seen from the implementation of lesson plan in the learning process. The average score for each stage was 4.0 for the organizing phase of the student to study, the analysis of the discovery process and feedback, making conclusions and evaluating the learning, conveying the motivation and objectives, presenting the results of the activities and evaluating the activity steps and guiding the students individually or group by explaining the instructional procedure, while the guiding phase of the discovery process and obtaining the data obtained a score of 3.5. The acquisition score in each phase showed that the implementation process was good. This suggests that teachers were able to properly manage learning using guided discovery methods. Implementation of the phases of learning that running smoothly, will affect student activities in the learning process. All student activities are recorded by two observers and the results can be seen in the following diagram 2;
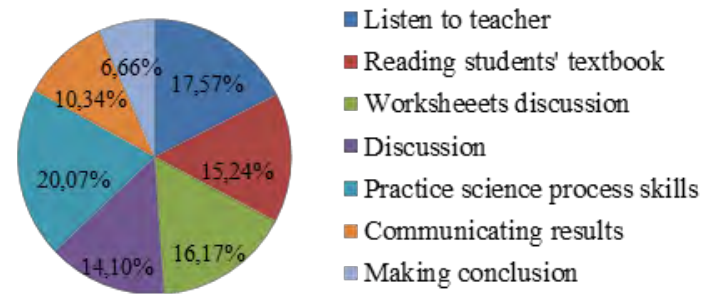

Fig. 3. Diagram of student activity average in the learning process

The results of the observation of student activity in Figure 1 , showed that the highest student activity was the science process skill activities of $20.07 \%$, and the lowest was conclusion formulating activities of $6.66 \%$. The high activity of students in science process skills because the science process skill activities was new activities for students, so that they can be as an interesting and challenging activities and can generate curiosity, so that all students are motivated to be active in the learning process. In addition, the teacher could also arrange a well-manage teaching learning process.

The results of this study are supported by another research that state that guided discovery method can increase student activity and mastery concept. Other studies have also shown that guided discovery learning can make students to engage in learning activities that build concepts independently [25] 
The measurement of the students' learning outcomes achievement were obtained by the preliminary and final test, were provided with 20 question items to measure the cognitive learning outcomes and 10 items to measure students' science process skills. The results are shown in Table 1 below:

TABLE 1. Achievement of student learning outcomes with Guided Discovery Method

\begin{tabular}{|c|c|c|c|c|c|c|c|}
\hline \multirow[t]{2}{*}{ No } & \multirow{2}{*}{$\begin{array}{l}\text { Learning } \\
\text { Outcomes }\end{array}$} & \multicolumn{2}{|c|}{$\begin{array}{c}\text { Average } \\
\text { Score }\end{array}$} & \multicolumn{2}{|c|}{$\begin{array}{c}\text { \% Mastery } \\
\text { learning of } \\
\text { Students }\end{array}$} & \multirow{2}{*}{$\begin{array}{c}\text { Sensitivity } \\
\text { of question } \\
\text { item }\end{array}$} & \multirow{2}{*}{$\begin{array}{l}\text { Gain } \\
\text { Score }\end{array}$} \\
\hline & & $P 1$ & $P 2$ & $\begin{array}{c}P \\
(\%)\end{array}$ & $\begin{array}{c}F \\
(\%)\end{array}$ & & \\
\hline 1 & $\begin{array}{l}\text { Cognitive } \\
\text { (Product) }\end{array}$ & $\begin{array}{c}18 . \\
8\end{array}$ & $\begin{array}{c}72 . \\
5\end{array}$ & 93 & 7 & $\begin{array}{c}0.30 \mathrm{~s} . \mathrm{d} \\
0.90\end{array}$ & 0.71 \\
\hline 2 & $\begin{array}{c}\text { Science } \\
\text { Process } \\
\text { Skills }\end{array}$ & $\begin{array}{c}17 . \\
7\end{array}$ & $\begin{array}{c}75 . \\
4\end{array}$ & 100 & 0 & $\begin{array}{c}0.37 \text { s.d } \\
0.77\end{array}$ & 0.71 \\
\hline
\end{tabular}

Learning outcomes consist of product cognitive learning outcomes and science process skills (Table 1). Comparision between pretest and posttest results, there has been an increase in learning outcomes both cognitive learning outcomes and science process skills. The average score of cognitive learning outcomes was 72.5 while the mean of science process skills was 75.4. This indicates that the implementation guided discovery of teaching learning method can increase the average score of student achiievement. The results showed that $\mathrm{N}$-gain score was high with $(\mathrm{g}) \geq 0,7$.

On the Competency-Based Curriculum Competence of students is determined by the educational unit. Based on the analysis of standard minimum criterion of science subjects in SMPN 1 Blega, students are decided to be complete in the teaching learning processes if it has reached the value of $\geq 65$. According to the criterion, the cognitive learning and science process skills completeness reaches $93 \%$ and $100 \%$ respectively. Students that were not mastery the competence yet maybe due to the passive working group that make peer tutor didn't occour in the group discussion. This is in line with the results of research which suggest that the use of guided discovery methods in groups of students with high creativity provides better learning outcomes achievement than achievement in conventional learning [25].

The results of the questionnaire to find out the students' responses to the learning of guided discovery methods are as follows: $100 \%$ of students feel interested and new to the subject matter/content, student book format, student worksheet, science process skill exercises, learning atmosphere and teacher facilitation. Even a $100 \%$ student stated clearly to the way the teacher facilitate science process skills (using tools, observing, communicating results, determining manipulation variables, determining response variables, determining control variables, conducting experiments, summing up data). Nevertheless, there are still students who still have difficulty in determining the variable manipulation, response variables, control variables, doing experiments, concluding the results with a range of $3 \%$ to $7 \%$.

The difficulties were faced by students, may come from: (1) the lack of students encouraged to enggage the activities in science process skills. Nevertheless some student showed even more interesting althought the new concepts and new advanted skills in science processes. Advanced skills consist of formulating hypotheses, identifying variables, defining variables operationally, designing investigations, conducting experiments, analyzing data, identifying the causes and effects of relationships among variables and formulating variables/ models. These advanced skills belong to integrated science process skills [26]. Basic science process skills should have been taught early so that students do not have dificulties to master the science process skills in a comprehensive way.

\section{CONCLUSION}

The implementation of guided discovery model could enhance the science process skill of Junior High School students on the concept of respiratory system. For further action in overcoming the obstacles that occur during the learning process, it is advisable: (1) to educators should use the guided discovery methods to enhance student learning outcomes and student process skills, (2) ) stimulate the learning environment to encourage the student as well as the good management classroom and allocate the appropriate time required.

\section{REFERENCES}

[1] K. Osman and S. H. A. Hamid, "Standard setting: inserting domain of the $21 \mathrm{st}$ century thinking skills into the existing science curriculum in Malaysia," Procedia-Social Behav. Sci., vol. 1, no. 1, pp. 2573-2577, 2009.

[2] H. B. Boholano, "Smart social networking: 21st Century teaching and learning skills," Istraživanja u Pedagog., vol. 7, no. 1, pp. 2129, 2017.

[3] H. A. Alismail and P. McGuire, "21st Century Standards and Curriculum: Current Research and Practice.," J. Educ. Pract., vol. 6, no. 6, pp. 150-154, 2015.

[4] K. P. D. Kebudayaan, "Materi Pelatihan Guru Implementasi Kurikulum 2013." Jakarta: Badan Pengembangan Sumber Daya Manusia Pendidikan dan Kebudayaan dan Penjaminan Mutu Pendidikan, 2013.

[5] E. Mulyasa and Mukhlis, Standar kompetensi dan sertifikasi guru. Remaja Rosdakarya, 2007.

[6] P. Turiman, J. Omar, A. M. Daud, and K. Osman, "Fostering the 21 st century skills through scientific literacy and science process skills," Procedia-Social Behav. Sci., vol. 59, pp. 110-116, 2012.

[7] S. Jalil, M. S. Ali, and A. Haris, "Development and validation of science process skills instrument in physics," in Journal of Physics: Conference Series, 2018, vol. 1028, no. 1, p. 12203.

[8] A. H. Zeidan and M. R. Jayosi, "Science Process Skills and Attitudes toward Science among Palestinian Secondary School Students.," World J. Educ., vol. 5, no. 1, pp. 13-24, 2015.

[9] E. H. M. Shahali and L. Halim, "Development and validation of a test of integrated science process skills," Procedia-Social Behav. Sci., vol. 9, pp. 142-146, 2010.

[10] N. Kruea-In and K. Buaraphan, "Enhancing lower secondary school science teachers' science process skill and laboratory lesson preparation through a social constructivist-based professional development workshop," Int. J. Sci. Math. Technol. Learn., vol. 20, pp. 43-56, 2014.

[11] J. M. Roschelle, R. D. Pea, C. M. Hoadley, D. N. Gordin, and B. M. Means, "Changing how and what children learn in school with computer-based technologies," Futur. Child., pp. 76-101, 2000.

[12] M. Q. Shihab, “ Membumikan” Al-Quran: fungsi dan peran wahyu dalam kehidupan masyarakat. Mizan Pustaka, 2007.

[13] A. Aydın, "Representation of Science Process Skills in The Chemistry Curricula for Grades 10, 11 And 12/Turkey," Int. J. Educ. Pract., vol. 1, no. 5, pp. 51-63, 2013.

[14] F. Karsli and A. Ayas, "Developing a laboratory activity by using 
5E learning model on student learning of factors affecting the reaction rate and improving scientific process skills," ProcediaSocial Behav. Sci., vol. 143, pp. 663-668, 2014.

[15] J. Paulo and C. Cruz, "Development of an experimental science module to improve middle school students' integrated science process skills," in DLSU Research Congress, 2015, vol. 3, pp. 1-6.

[16] Z. Yakar and H. Baykara, "Inquiry-Based Laboratory Practices in a Science Teacher Training Program.," Eurasia J. Math. Sci. Technol. Educ., vol. 10, no. 2, 2014.

[17] A. O. Akinbobola and F. Afolabi, "Constructivist practices through guided discovery approach: The effect on students' cognitive achievement in Nigerian senior secondary school physics," Eurasian J. Phys. Chem. Educ., vol. 2, no. 1, pp. 16-25, 2010.

[18] Y. L. Sulastri, D. Wahidin, H. S. Muchtar, and Z. W. Lestari, "THE IMPLEMENTATION OF ACTIVE LEARNING MODELS TO INCREASE PRE-SERVICE TEACHERS'HIGH ORDER THINKING SKILLS," PEOPLE Int. J. Soc. Sci., vol. 2, no. 1, 2016.

[19] L. J. Achera, R. R. Belecina, and M. D. Garvida, "The Effect of Group Guided Discovery Approach on Theperformance of Students in Geometry," Int. J. Multidiscip. Res. Mod. Educ. (IJMRME), I, pp. 2454-6119, 2015

[20] F. J. J. M. Janssen, H. B. Westbroek, and J. H. van Driel, "How to make guided discovery learning practical for student teachers," Instr. Sci., vol. 42, no. 1, pp. 67-90, 2014.

[21] Y. Yuliana, T. Tasari, and S. Wijayanti, "The Effectiveness Of Guided Discovery Learning To Teach Integral Calculus For The
Mathematics Students Of Mathematics Education Widya Dharma University," Infin. J., vol. 6, no. 1, pp. 1-10, 2017.

[22] S. Sucipta, "Metode Guided Discovery Learning terhadap Tingkat Berpikir Kritis Siswa Dilihat dari Motivasi Belajar," Indones. J. Econ. Educ., vol. 1, no. 1, 2018

[23] C.-J. Shieh and L. Yu, "A Study on Information Technology Integrated Guided Iscovery Instruction towards Students' Learning Achievement and Learning Retention.," Eurasia J. Math. Sci. Technol. Educ., vol. 12, no. 4, pp. 833-842, 2016.

[24] A. Karim, "Penerapan metode penemuan terbimbing dalam pembelajaran matematika untuk meningkatkan pemahaman konsep dan kemampuan berpikir kritis siswa sekolah dasar," J. Pendidik., vol. 1, no. 1, pp. 21-32, 2011

[25] K. P. Wibowo and M. Marzuki, "Penerapan Model Make a Match Berbantuan Media Untuk Meningkatan Motivasi Dan Hasil Belajar IPS," Harmon. Sos. J. Pendidik. IPS, vol. 2, no. 2, pp. 158-169, 2015 . 